\title{
An Exploratory Study of Hong Kong Mathematics Education of International Schools and Public Schools
}

\author{
Xiaoyu Xu, Chi-Wai Yu \\ Mathematics department, Hong Kong University of Science and Technology, Hong Kong, China
}

\begin{abstract}
This study explored the difference in the belief on mathematics teaching between teachers of International and public schools; In particular, it considered the beliefs of middle school teachers with regard to mathematics. This study also soldiered the relationship between teachers 'conceptions and students' attitude of learning mathematics. It employed the mixed method and design to identify the three different types of questionnaires were designed for 19 teachers, and 107students from five different schools. All statistical analysis were implemented by an open-source package, R. Some characteristic features affecting on teachers' belief, conceptions, and students' attitude were observed. Hence, there is a sightly effective relationship between the students' personality relate with the teachers' belief.
\end{abstract}

Keywords: Mathematics teachers' belief, International Baccalaureate teachers' conception

\section{Background}

Mathematics education is a theoretical and autonomous science, based on a conceptual system and on original methods of inquiry that are not borrowed from close disciplines and that are aimed at studying the phenomenon of mathematics teaching in its complexity and seen in its context (concepts mostly developed in France after Brousseau, 1986). In other words, mathematics teachers are responsible for simplifying abstract concepts for students to understand. Teachers' conceptions of mathematics and mathematical pedagogy were found to affect their pedagogical decisions, which then affect the learning of their students (e.g., Cross, 2009; Ernest, 1989; Staub \& Stern, 2002). As acknowledged by many research findings, teachers' knowledge, belief, and awareness have a significant impact on students' learning. In this study, teachers' belief in mathematics teaching and learning is an important factor to be discussed.

International Baccalaureate (IB) aims to develop inquiring, knowledgeable and caring young people who help to create a better and more peaceful world through intercultural understanding and respect. IB encourages students across the world to become active, compassionate and lifelong learners who understand that other people, with their differences, can also be right. Within the prescribed framework, IB students are able to apply mathematics to authentic real-life situations, and to discover mathematical patterns. The IB program (Middle School Program MYP) shows specific ATL (approaches to learning) skills that students can demonstrate through performances of understanding in mathematics.

Communication skills is one of the skills to organize and interpret data using both analog and digital tools. Critical thinking is another skill which requires students to draw justifiable conclusions and generalizations from investigating. In the IB MYP program, conceptual understanding is framed by prescribed key and related concepts. Teachers must use these concepts to develop the curriculum. Schools may identify and develop additional concepts to meet local circumstances and curriculum requirements.

ISSN: 0010-8189

(C) CONVERTER 2020

www.converter-magazine.info 
Teachers in IB schools are also required to follow that teaching methodology and adopt a learner-centered teaching approach (Mathematics guide, 2013). Therefore, it is significant to observe the difference in the belief in teaching methodology between teachers in international schools and teachers in public schools.

\section{Methods}

Majority of investigations of the relationship between teachers' beliefs and students' traits have been qualitative studies of a few number of teachers. However, the questionnaire can present the number of have been conducted using quantitative methods with large samples of teachers. This study was conducted by questionnaire, a method appropriate for investigating between psychological test and algebra test (Clarke \& Stephensy, 1994). However, one of the limitations of the survey method is the reliance on self-reporting, is measurement error that may the constant or variable, so aware of this in the interpretation of the results.

Table 1.Two experiments explanation

\begin{tabular}{|c|c|c|}
\hline & Task I & Task II \\
\hline Participants & $\begin{array}{l}107 \text { Grade } 8 \text { students } \\
5 \text { teachers, } 3 \text { from international schools and } 2 \text { from public } \\
\text { schools international schools } \\
\text { Students took the test at different times, time variable is } \\
\text { not considered in this study } \\
\text { A, B, and C represent international schools, while D and E } \\
\text { indicate public schools. }\end{array}$ & $\begin{array}{l}19 \text { teachers, } 10 \text { from public schools } \\
\text { and } 9 \text { from international schools }\end{array}$ \\
\hline $\begin{array}{l}\text { Task } \\
\text { Explanation }\end{array}$ & $\begin{array}{l}\text { The test consists of two parts; one is an algebra test and } \\
\text { the other is a psychological questionnaire. } \\
\text { The algebra test has } 9 \text { algebra expansion questions; } 2 \text { are } \\
\text { multiple choice questions, and } 7 \text { are short problems. } \\
\text { The psychological test has } 8 \text { questions; some are related to } \\
\text { their attitudes towards mathematics learning and some are } \\
\text { related to students' thinking about their course. Several } \\
\text { questions are similar to course evaluation questionnaires. } \\
\text { Each question worth } 2 \text { points, total points of test is the } 18 \\
\text { points }\end{array}$ & $\begin{array}{l}\text { Teachers are asked to complete a } \\
\text { questionnaire eliciting information } \\
\text { about: a) her or his teaching belief } \\
\text { and experience b) the target course. } \\
\text { The main focuses are on teachers' } \\
\text { background information, teaching } \\
\text { methodology, and personal teaching } \\
\text { philosophy. In each mathematics } \\
\text { lesson, teachers ought to arrange the } \\
\text { percentage of the activities, which } \\
\text { are listed in administrative tasks, } \\
\text { homework review, lecture-style } \\
\text { presentation by the teacher, teacher- } \\
\text { guided student practice, re-teaching } \\
\text { and clarification of content, student } \\
\text { independent practice, and tests } \\
\text { and quizzes parts. }\end{array}$ \\
\hline Purpose & $\begin{array}{l}\text { We want to investigate whether students feel comfortable } \\
\text { with the course or not. }\end{array}$ & $\begin{array}{l}\text { We want to distinguish different } \\
\text { kinds of teachers thinking and } \\
\text { belief. }\end{array}$ \\
\hline
\end{tabular}

ISSN: 0010-8189

(C) CONVERTER 2020

www.converter-magazine.info 


\begin{tabular}{|l|l|l|}
\hline Procedure & Duration of the tests: $45 \mathrm{mins}$ & Duration of the tests: 30 mins \\
& No hints are given. \\
& No calculator is allowed. \\
All questionnaires should be taken by students and did it & independently. \\
& No discussions are allowed.
\end{tabular}

\section{Results}

3.1 This study aims to address three research questions.

- RQ1: What is the difference in the beliefs in mathematics teaching between international schoolteachers and public schoolteachers?

- RQ2: What is the relationship between the students' test results and teachers' personal beliefs?

- RQ3: What are the teaching requirements of International Baccalaureate program? What are the teaching conceptions of teachers from international schools?

\subsection{Exploratory data analysis of algebra test}

Question: Which school has the highest total point in the test?

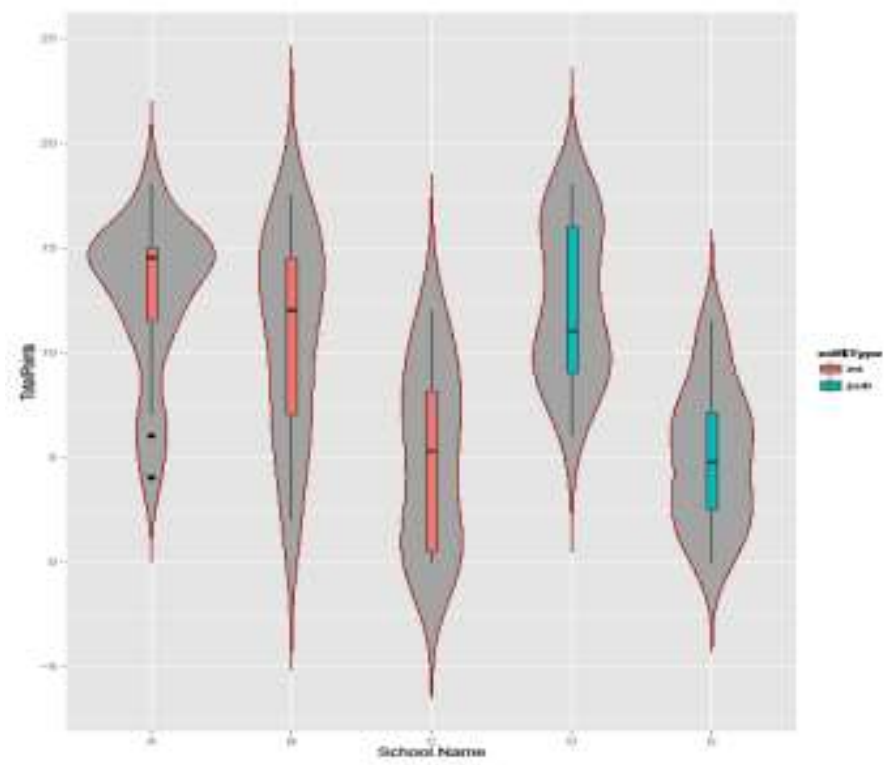

Fig 1: Range of students test result

To know whether the difference between five schools' means are statistically significant. Using one-way Anova test, in the result, the null hypothesis states that mean of total points of five different schools are equal. Because the p-value is $7.55 \mathrm{e}-13$, which is less than the significance level of 0.05 , we can reject the null hypothesis and conclude that five schools have different means. As we can see from Figure 1, school A, B and D has a higher median score than school C and D. Students from school A and E have a high level of similar grade with each other. In fact, students from school C, B, and D have a quite different scores on the

ISSN: 0010-8189

(C) CONVERTER 2020

www.converter-magazine.info 
test. According to the violin plot graph figure 1, school A, B, D have higher probability of total points from 15 points to 20 points, and school $\mathrm{C}$ and $\mathrm{E}$ have higher probability of total points from 5 to 10 .

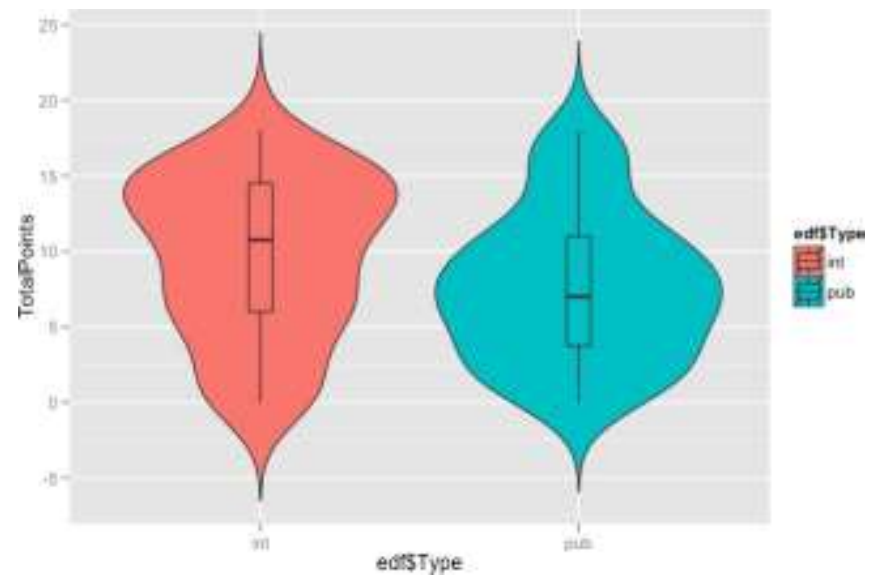

Fig2: The total scores of International schools and public schools' students

Furthermore, to discuss the difference between public schools and international schools is necessary important. Using one- way ANOVA model to compare the mean of total points between international and public schools, the p-value is 0.0418 , and we conclude that there is a significant difference means of total points between international schools and public schools. As we can see from Figure2, international school has higher mean than the public schools, which is 9.605769. The mean of public school is 7.581818 . Surprisingly, in the violin plots, the shape of graphs looks like leaves, the high probability of total points of international school is on the top of the leaf but public school is on the bottom of the leaf.

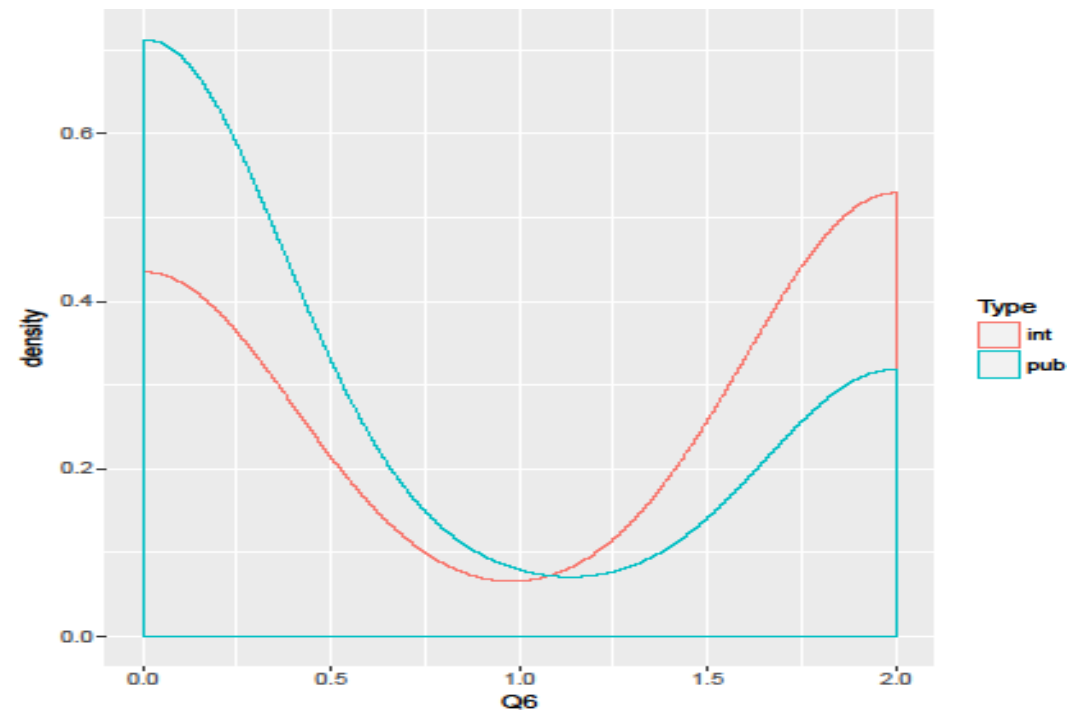

Fig 3: The Q6 density

From Figure 3, Students in international schools achieve grades more closely to each other. However, the grades students in public schools achieve are comparatively more fluctuating. What factors affect students' result. Next, the result of question 5 will be analyzed to examine whether the hypothesis is reasonable. School A achieves the highest scores. The other two international schools, B and C, have higher scores than the public schools, D and E. Interestingly, the majority of students of school D and E scores zero. 
a) Question 6: Our club shirts are available in two sizes: small shirts cost \$27 each and large shirts cost \$31 each. Last week 14 shirts were sold with total cost\$398. How many of each shirt size were bought?

b) Question 5 Canned peaches come in two sizes. Small cans cost $\$ 2$ each and large cans cost $\$ 3$ each. If 15 cans of peaches are bought for total of $\$ 38$, how many small cans were purchased?

Based on 2a) and 2b), we can easily get conclusion public schoolteachers and international schoolteachers have different belief or methodology that cause the difference in results.

c) What is the relationship between teachers' personal beliefs and the scores of open-ended questions?

Teachers from international schools strongly agree that well-prepared activities, effective teaching style and formative and summative assessments are crucial. In terms of teaching methodology, teachers should allow students to work in pairs or small groups under teacher's assistance.

For the real-life question (Q6), teachers from international schools firmly believe that the ability of students in providing reasons to support their conclusions is distinctly important.

d) How to set up an algebraic expression?

The majority of students in public schools like to set the unknown variable as $\mathrm{X}$, however, some students from international schools prefer to use their own letter to represent the unknown variable. For instance, if the volume of tank is unknown and asked, they would use $t$.

e) How do students comment on the questionnaire?

Some students from international schools have written numerous interesting comments, some of them are suggestions of the questionnaire and some of them are unrelated with answers. Refer to Figure 5 below; the comments reflect their critical thinking about a particular question in the questionnaire.

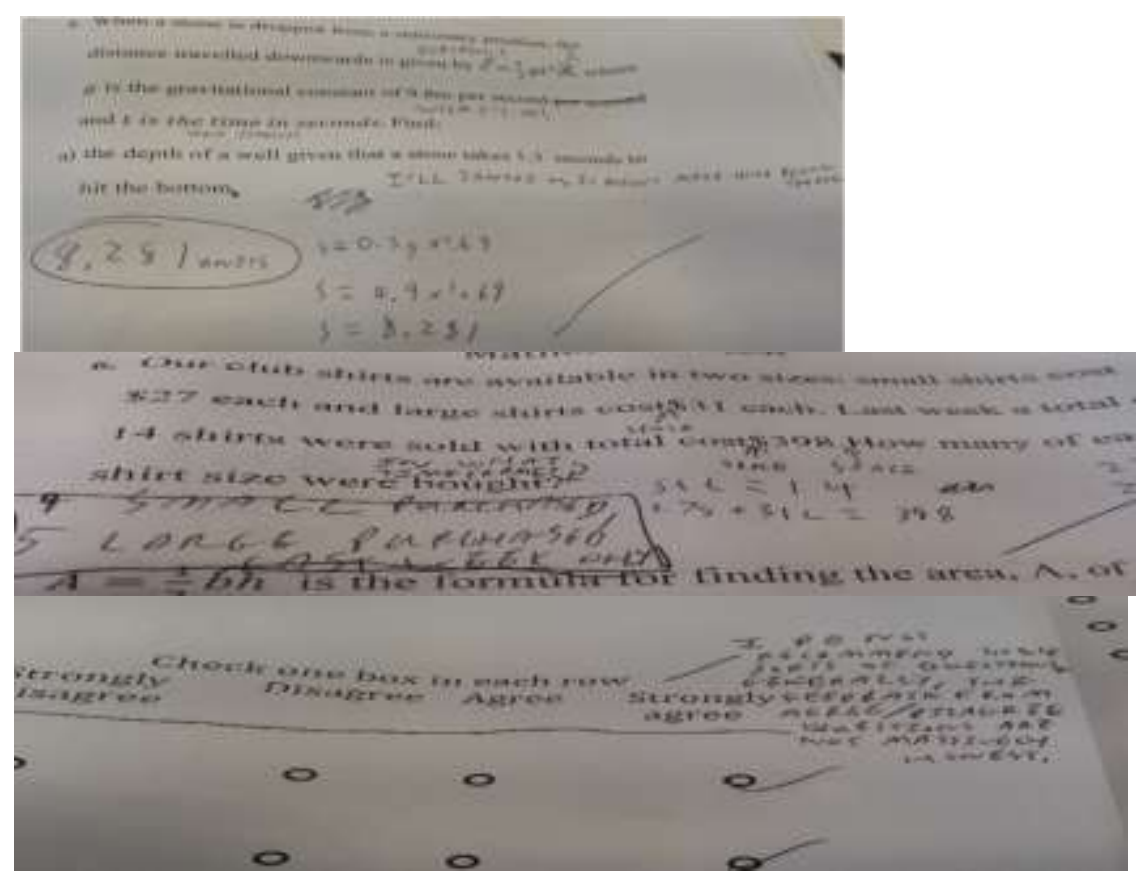

Fig 4: The answer of students' explanation

ISSN: 0010-8189

C CONVERTER 2020 
a) What is the relationship between teachers' personal beliefs and the scores of open-ended questions? Teachers from international schools strongly agree that well-prepared activities, effective teaching style and formative and summative assessments are crucial. In terms of teaching methodology, teachers should allow students to work in pairs or small groups under teacher's assistance. For the real-life question (Q6), teachers from international schools firmly believe that the ability of students in providing reasons to support their conclusions is distinctly important.

b) How to set up an algebraic expression?

The majority of students in public schools like to set the unknown variable as X, however, some students from international schools prefer to use their own letter to represent the unknown variable. For instance, if the volume of tank is unknown and asked, they would use t.

c) How do students comment on the questionnaire?

Some students from international schools have written numerous interesting comments, some of them are suggestions of the questionnaire and some of them are unrelated with answers. Refer to Figure 5 below; the comments reflect their critical thinking about a particular question in the questionnaire.

\subsection{Exploratory data analysis of psychological questionnaire}

The result of psychological questionnaire that the lowest mean of the two questions involves whether students feel interesting in their classes and whether students like their mathematics' homework. However, two other statements have an opposite result, which are whether students want to improve their mathematics' grade and whether students believe that practice can improve their mathematics' scores. Moreover, the question that whether students like to communicate with their friends when they meet difficult mathematics questions has a strong mean of 1.019. This is very close to the median. (Refer to appendix for boxplot) One thing it can be sure of is that those nine different statements test students' attitudes towards mathematics. $76.19048 \%$ of students agree that mathematics is important for their life. Compared the proportion of public schools and international schools, say $\mathrm{p}_{\mathrm{int}}-\mathrm{p}_{\mathrm{pub}}$, the true value of test $\mathrm{P}_{\mathrm{int}}$ is significantly greater than that of $\mathrm{P}_{\mathrm{pub}}$, which is significant. It is no doubt that most students do not like their mathematics homework. Communication is one meaningful factor to be discussed; all three international schools ensure and believe that communication is important especially when students meet difficult questions.

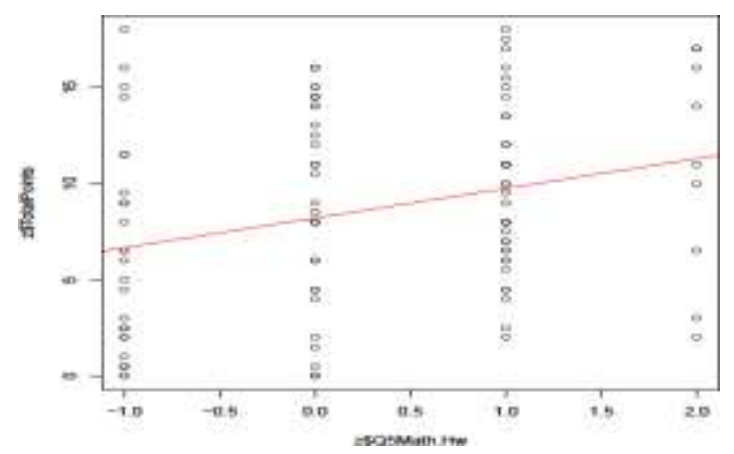

Fig 5: The coefficient of students with total sores and students 'psychological

For figure 5, Students who feel more comfortable with their homework comes from the school with a higher mean of total scores. Furthermore, there is strong correlation relationship between them. The intercept of the relationship is 7.618 , and the coefficient is 1.972 .To observe the $\beta$ because to test whether the linear regression model is useful for prediction we have to test whether the explanatory variable X (Q5.Math.Hw) has a significant effect on Y(TotalPoints) or not. The p-value of Q5Math.Hw is the 0.00419, which mean

ISSN: 0010-8189

C CONVERTER 2020

www.converter-magazine.info 
the $\beta$ is significantly different from zero. There is significant effect of students' attitude about homework on their totalpoints of the test.

In the earlier discussion, additionally, it is necessary that investigate teachers' belief. Public teachers and international teachers have difference of belief and methodology. Personal theories and beliefs about mathematics, teaching, learning and students; the nature of student assessment (eg.External-internal, traditional-alternative); the character of education system (eg. Centralized- decentralized, goals for teaching mathematics at school); participate parties (eg. Principal, supervisor, parents, colleagues)( Lyn D. English. "International research in mathematics education." Journal of teacher understand of students learning, (2002): 227.) That is unreasonable to assume that there is a relation or connection between teachers' belief and students' learning. In generally, finding some common factors effect teachers' thinking, public schoolteachers and international schoolteachers have same figures, which on they all believe the students answer each question should have the ability to explain the reasoning behind the idea. They are in agreement on the letting students work individually without assistance from the teacher. Students work individually with assistance from the teacher is significant important during their teaching. On the other hand, International schoolteachers believe that students should be able to think creatively is important for students' further study. Nevertheless, public schoolteachers disagree with the statement. Another huge difference of the statement is work together as a class or in pairs or small group with the students responding to one another.

International schoolteachers have a much higher mean than those public schoolteachers have. It seems international school teachers prefer more activities than the public-school teachers do, which likes students to work together in small groups or pairs.

Moreover, if students get into debates in class about ideas or procedures in mathematics; it can harm their learning. All international schoolteachers strongly disagree with this statement; however, public school teachers reflect a strong agreement on it. Formative assessment is to monitor student learning to provide ongoing feedback that be used by instructors to improve their teaching and by students to improve their learning. Formative assessments help students identify their strengths and weaknesses and target areas that need work which such as turn in a research proposal or draw a poster in class to present their understanding of a topic (Carnegie Mellon University, Formative vs Summative Assessment, 2008).

Summative assessments are cumulative evaluations such as chapter tests, end of term exam or semester exams. International schoolteachers assert that providing formative assessment is important, but public schoolteachers do not. Thus, it is necessary to observe the percentage of time teachers spent on different activities in a mathematics class. Teacher-guided students practice has the highest mean among all activities. Surprisingly, public schoolteachers prefer to do administrative tasks than international schoolteachers.

\section{Conclusion}

This study explored the teachers' beliefs in HongKong international schools and public schools in HongKong. For Math teachers' life's experiences can influence their beliefs system and the latter correspondingly influences vary which may change their beliefs system hence, examining the nature of such change is imperative A great deal of research has been done on how we learn, leading figures such as Lev Vygotsky and his Zone of Proximal Development (ZPD) (Vygotsky, 1978) which indicates that there is a gap between what a learner can learn without support and what they can learn with support, this support or scaffolding can be provided by the teacher or the students in the classroom to the wider community. Engaging students in the classroom is vital to achieving learning and my motto as such is "Active EngagedmLearning". Encouragement should be given to every student in the class whenever they attempt a question, regardless of whether the answer is right

ISSN: 0010-8189

C CONVERTER 2020

www.converter-magazine.info 
or wrong. Pairing weaker students with stronger ones who can then encourage and support their each other is also essential, this is their ZPD.

Within the educational field there is also a focus on the learning styles of students and catering for those styles in the classroom. There are three accepted learner styles, those being, visual learning by way of sight, auditory learning by way of sound and kinesthetic learning through movement and activity (VAK). It is widely considered that kinesthetic methodologies are the most underused in the classroom. A lack of kinesthetic activities in the classroom contributes to the reason why many students leave mainstream western education at the age of 16 to pursue other avenues of education/employment, with many choosing vocational qualifications.

\subsection{Research question 1}

RQ1: What are the differences in the beliefs in mathematics teaching between international schoolteachers and public schoolteachers?

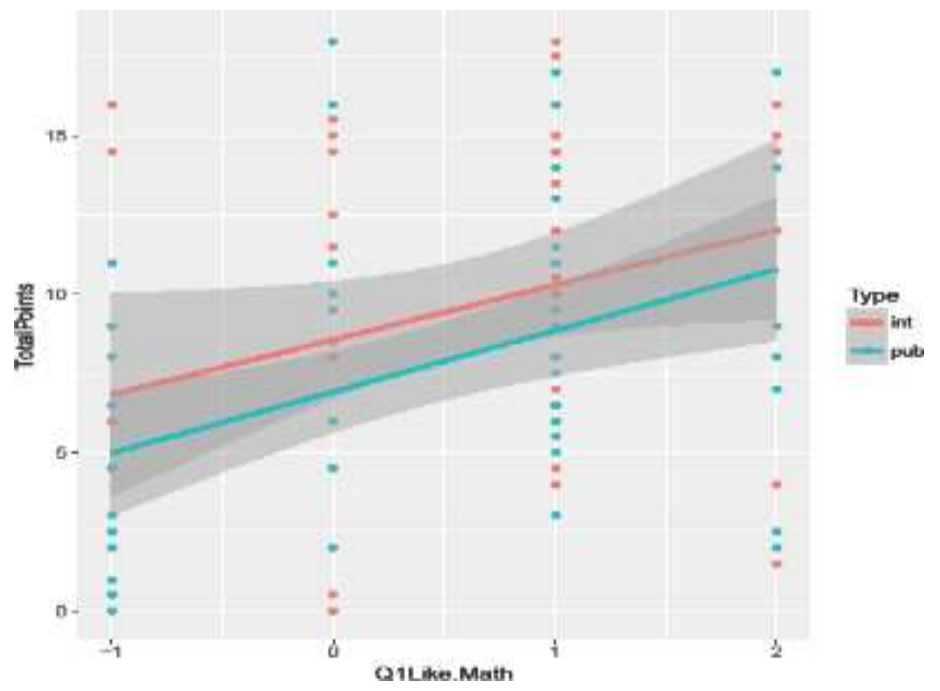

Fig 6: Q1Like Math \& Total Points

As we can see from Figure 8, international schools has a higher slope than public schools, both fitting line are straight. As we see the boxplot of appendix, Students from international schools like mathematics more than students from public schools. To know an inference about the true difference in proportions, say $\mathrm{p}_{\text {int }}-\mathrm{p}_{\text {pub. }}$ Pvalue is $1.467 \mathrm{e}-11$, which is absolutely smaller than the 0.05 . We can reject null hypothesis, and conclude that the between proportion of international schools and public schools is significantly different.

Bâsed on the circumstance above, from the results of Task II, international schoolteachers firmly believe the students should be able to think creatively. This can easily be supported by the result of the open-ended question from Q.9 in Task I. For the real life context problem from Q.6 in Task I, students from international schools A and B achieve good scores. Although students from international school C achieve a slightly lower score, students try to write some comments on the question. Moreover, from Figure 8, Q1Like.Math has a positive effect on Total Points, which shows that the two variables interact with each other. It is necessary to set formative assessments to stimulate students' interest. It is necessary that analyze the relationship between students' general attitude toward math (Q1.LikeMath) and their attitude about the specific course(Q4.class.inte) It is easier to get two equations: $y=0.08328+0.61917 Q 1$ Like. Math $y=0.23026+0.64238 Q 4$ class. inte. Both of p-value of them are 0.00494 and 7.24e-13, which are significant difference between Q1.LikeMath and Q4.class.inte. According to the all circumstance above, we can conclude that students have great learning

ISSN: 0010-8189

(C) CONVERTER 2020

www.converter-magazine.info 
experience effect their attitude about the subject, which also affect their grade of the subject. In addition, more time and energy should put on studying mathematics in order to arouse their interest. In order to assist students to understand the formula in mathematics and procedure of solving mathematical problem, activities are important in the learning and teaching process. In mathematics lessons, students often work together as a class or small groups or in pairs with students. It is a good approach to student-centered learning conception. Student-centered learning puts students' interests first, acknowledging student voice as central to the learning experience. Student-centered learning space is emphasize on students to become the center of class. They can choose what they will learn, how they will learn, and how they will assess their own learning. A student-centered learning environment encourages students to become independent learners and ultimately to be in charge of their own education. (George lucas educational foundation, 2017) On the other hand, all teachers from international schools disagree with the statement that debating in class can harm students' learning. In other words, communication is a meaningful factor.

Public school teachers strongly believe that built clearly problems, and that letting students to remember mathematical formula and procedure is important. They have highly confirmed that lecture- style presentation by teacher is their usual way in conducting a lesson, namely, traditional education.

\subsection{Research question 2}

RQ2: What is the relationship between the students' test results and teachers' personal beliefs?

Based on task I and II, communication is an important factor to relate with teachers' belief. Both questionnaires involves question in understanding students' studying habit. The questions below are analyzed to establish a connection between teachers' belief and students' attitude.

1. Students' questionnaire: Do you like to communicate with your friends when you meet difficult mathematics questions?

2. Teachers' questionnaire: In your mathematics lessons, how often do you usually ask students to do the following? Statement: Explain the reasoning behind an idea.

3. Teachers' questionnaire: To what extent do you agree or disagree with each of the following statements? If students get into debates in class about ideas or procedures covering the mathematics, it harm their learning.

From the observation, international schoolteachers strongly disagree with the third question, and their students prefer to communicate with their friends, which is one of the teachers' goals during each lesson. Moreover, some students write some comments on the short problems, which is a strong evidence showing that teachers' belief affect students' learning habit.

After that, observed other three questions, it is not hard to get new information.

1. Students' questionnaires: Do you think mathematics is important for our life?

2. Teachers' questionnaires: To what extent do you agree or disagree with each of the following statements? Mathematics is primarily an abstract. Mathematics is primarily a formal way of representing the real world.

3. Students' test: Q6 (the real-life question), and Q9 (the open-minded question).

Statistically, it is shown that Like Math and Communication factor are important for International Baccalaureate program. Analyze the data with multiple linear regression model to find how the Total Points

ISSN: 0010-8189

(C) CONVERTER 2020

www.converter-magazine.info 
is related with the change in the Q1Like.Math and the change in the Q8.Communicate, Q7 practice, Q4Class.int and Q9.Expect A as a secondary explanatory variable. The results are shown below:

^ $y=7.57097+1.95099$ Q1Like. Math $+0.088997 \mathrm{Q} 7$ practice. The general p-value is 0.0005116 , and $\mathrm{p}$-value for Q1.Like.Math is 0.000695 , but Q7practice is 0.876767 .

However, running for Q8communicate factor, the equation is

$\hat{y}=6.23126+1.7598 * Q 1$ Like. Math $+1.4128 * Q 8$ communicate. The general p-value is 8.794e-06, and p-value for Q1.LikeMath is 0.000395 , and Q8communicate is 0.004399 and Looking for class interesting factor, $\hat{y}=7.5576+1.3534 * Q 1$ Like. Math $+1.03534 * Q 4$ Class. int The general p-value is 0.0001433 , and $\mathrm{p}$-value for Q1.LikeMath is 0.0333 , but for Q4class.inte is 0.1098 .

Next, for the Expect.A variable,

$y^{\wedge}=7.0034+1.5722 *$ Q1 Like. Math $+1.1403 Q 9$. Expect $A$. The general p-value is $1.754 \mathrm{e}-05$, and $\mathrm{p}$ - value for Q1.Like Math is 0.00289, also for Q9.Expect. A is 0.01587.

Lastly, it seems that all of those factors have a high correlation. The highest correlation is the variable Q8.communciate, and it has a significant effect on the TotalPoints factor. All of functions p-value are smaller than the significant level 0.05, for the factors part, the p-value Q9ExpectA and Q8communicate are smaller than the significant level 0.05. It means that those two variables have a strongly effect on the Total Point.

\subsection{Research question 3}

RQ3: What are the teaching requirements of International Baccalaureate program? What are the teaching conceptions of teachers from international schools?

International Baccalaureate requires teachers believe that centers on learners, develops effective approaches to teaching and learning, works within global contexts, helping students understand different languages and cultures.

For MYP, it is a challenging framework encourages students to make practical connections between their studies and the real world. This is the key concept relating to our real-life studies.

Learner-centered and positive encouragement environment are important to teaching and acquisition of learning. Beliefs are influential on teachers' decision of teaching methodology and style. Setting real-life context question is a good way to help students develop a deeper understanding on mathematical concepts. Clearly, students should not only memorize the formula and procedure of those mathematics questions in their learning process.

\section{References}

[1]. J.G. Brousseau. Fondements et methods de la didactiques des mathematiques. Recherches en Didactique des Mathenatiques, vol: 7, pp. 33-115, 1986.

[2]. D. I.Cross, Alignment, cohesion, and change: Examining mathematics teachers belief structures and their influence on instructional practices. Journal of Mathematics Teacher Education, vol: 12, no:5, pp.325-346, 2009.

[3]. P. Ernest, The knowledge, beliefs and attitudes of the mathematics teacher: A model. Journal of Education for Teaching, vol: 15, no:1, pp. 13-33, 1989.

[4]. Joan. Gorham. "The relationship between verbal teacher immediacy behaviors and student learning." Communication education. vol:3, no:1, pp. 40-53, 1988.

[5]. F. C. Staub \& E. Stern. The nature of teachers' pedagogical content beliefs matters for students'

ISSN: 0010-8189

(C) CONVERTER 2020

www.converter-magazine.info 
achievement gains: Quasi-experimental evidence from elementary mathematics. Journal of Educational Psychology, no:94, pp. 344-355, 2002.

[6]. A.G.Thompson. Teachers' belief and conceptions: A synthesis of the research In D. Grouws (Ed.), Handbook of research on mathematics learning and teaching.New York: Macmillan, pp.127145,1992 .

[7]. Mathematics guide. Mathematics guide for use from September 2014/ January2015, Middle Years program, international Baccalaureate, pp12-23, 2013.

[8]. Wikipedia.Student-centred learning, Wikipedia. the free encyclopedia, 2017.

[9]. George lucas educational foundation George lucas educational foundation, edutopia, studentcentered learning environments: How and why 20, 2017. 